\title{
INNOVATION OF INTEGRATIVE-INTERCONNECTIVE ISLAMIC EDUCATION BASED ON DIRECT EXPERIENCE IN UNIVERSITAS BRAWIJAYA MALANG
}

Nur Chanifah

Fakulty of Law, Universitas Brawijaya, Jl. MT. Haryono 169 Malang

Email: nur.chanifah@ub.ac.id

\begin{abstract}
The implementation of religious education faced various internal problems, such as its learning methodology and externals, such as strengthening the culture of materialism, consumerism, and hedonism, which has led to changes in people's lifestyles. In this context, Islamic education innovations need to improve the quality of Islamic education learning to address globalization's challenges today. This study aims to find Islamic education learning innovations that are integrative-interconnective based on direct experience in Brawijaya University. Therefore, this research included case study research with data collection techniques using interviews, observation, and documentation. Data analysis uses descriptive-qualitative analysis. The study results show that Islamic education innovation in Brawijaya University covers several things, namely the paradigm, approach, strategy, method, and learning evaluation system. The learning paradigm changed from dichotomous to integrative-interconnective; the learning approach oriented towards student-centered with focus, namely problem, spiritualscientific, and philosophical-normative. Learning strategies cover direct instruction, contextual teaching and learning, problem-based learning, and meaningful learning. Learning methods are oriented to direct experience. Simultaneously, the evaluation not only leads to cognitive aspects but also affects affective and psychomotor aspects by using observation and self-assessment techniques. The implications for understanding students are getting better. It can saw in the result of student grades.
\end{abstract}

Keywords: Learning innovation, Integrative-interconnective, and direct experience

\section{Introduction}

Currently, the implementation of religious education considered to be less successful in working on religious attitudes, behavior, morals, and ethics development. Many arguments put forward to strengthen these statistics, among others, are indicators of weaknesses inherent in the implementation of Islamic Education. (Muhaimin, 2014)

In the context of higher education or University, like Brawijaya University, there are many Islamic education problems. They are the ratio between the number of lecturers and students who are not balanced. Islamic education learning is given only two credits in one semester. The spread of Islamic education subjects that not balanced every semester further aggravates the burden of lecturers of Islamic education. They teach up to 15-20 classes in one semester. These conditions certainly make it harder for PAI lecturers to develop student character.

Various internal issues of Islamic education have not yet solved adequately. (Hamka, 2009) On the other hand, Islamic education faced a variety of external factors, including strengthening the culture of materialism, consumerism, and hedonism, which has led to changes in people's lifestyles. We can see this as there are still 
many deviant attitudes and behaviors found in society (demoralization). (Brill, 2003)

Islamic education structure is decline; the Islamic society took to dichotomy with secular and religious education. (Said, 2018). They can never be isolated to develop society. Integrated Islamic education can make students understanding optimally and comprehensively.

The syllabus of Islamic Education courses developed at University precisely reflects the dichotomic atomistic paradigm. Therefore, awareness to correct the dichotomy of religious studies and multidisciplinary is an urgent demand. The epistemology reintegration project of religious studies and multidisciplinary that needs for closer dialogue and collaboration between religious studies and multidisciplinary in the future. A multidisciplinary approach prioritized so that there is no learning dichotomy. (Hanafi, 2016)The approach of Islamic education influenced by historical, cultural, social, and political factors. However, both the Islamic studies and multidisciplinary must be integrated and connected.

In this context, Islamic education learning innovations must improve the quality of Islamic education learning to be able to answer the challenges of globalization today. It is as shown by the research of Nur Saidah (Saidah, 2007), Asep Mahpudz
(Mahpudz, 2011), Abdul Munip (Munip, 2008), that the problems faced start from the conceptual confusion of the Islamic education course itself, the minimal portion of credits for an ideal goal, namely personality development.

Besides, the orientation of the material and its evaluation are still cognitivist, have not touched affection let alone build awareness, and the diversity of students' religious backgrounds. Therefore, Islamic education learning needs to redesigned to be effective so that it can contribute to shaping students' character.

Several studies try to provide solutions to these problems, including research by Syukri Fathudin Achmad Widodo (Widodo, 2009), Sumarno (Sumarno, 2008), and Abdul Gafur. However, the research did not cover all aspects of Islamic education learning, only aspects of learning planning (syllabus and learning preparation). Thus, there is no comprehensive research on Islamic education learning at Higher Education in students' Islamic character development.

In this case, the author tries to examine Islamic education learning innovations in Universitas Brawijaya, namely integrative-interconnective Islamic education learning based on direct experience to foster student awareness. Islamic education must be integrated into other subjects because it correlates with 
them. It is an approach that seeks mutual respect, such as the general science and religion, aware of their particular limitations in solving human problems. It will give birth to collaboration at least understand each other's approach and methods of thinking (process and procedure) between the two sciences. (Hidayat, 2014)

Islamic Education Learning also needs to contain integrative-interconnective scientific approaches and paradigms, so that the learning process delivered by lecturers becomes comprehensive. The understanding generated from integrative Islamic Education learning will lead students to learn in totality and make Islamic education part of the real-life needed by them. It will not happen if the understanding of Islamic education is isolative or separate from other sciences. This condition can give the impression that religion only deals with divinity and the hereafter. In contrast, modern sciences related to humans and life in the world. Concerns about the impact of the separation of knowledge can void through an integrative learning process.

The previous research relating to the integrative-interconnective approach is Hidayat research, which explains how integrative-interconnectivity implemented in Islamic education. However, its research does not discuss its implementation in University. Based on the previous research, reality, and arguments above, it is essential to conduct a study of integrativeinterconnectivity of Islamic education learning innovations.

\section{Integrated-interconnected}

Islamic Educatioan in University

The concept of integrationinterconnection was the first echo by Amin Abdullah, a former Chancellor of the Islamic State University of Sunan Kalijogo. According to him, the concept is an attempt to understand the complexity of the life phenomena faced and carried out by humans in any scientific development, whether religious knowledge (Islam or other religions), social science, humanities, or indepth. In this case, various disciplines cannot stand alone without cooperation, greeting each other, needing each other, mutual correction, and interconnectedness between scientific disciplines. Furthermore, the concept seeks mutual respect for general science and religion, is aware of each other's limitations in solving human problems, so there is a need for cooperation with the mutual understanding of approaches and methods of process and procedures between the two sciences.

Whereas according to Khoiruddin Nasution that integration requires the existence of relations or unification or synchronization or greeting or parallels between each existing scientific field. Every scientific field cannot stand alone, without greeting each other with other scientific 
fields. This greeting situation, can occur/appear inductively, integrally (fused in the discussion), can also be in a comprehensive discussion (completeness of aspects of the review), interdisciplinary in the sense of various reviews, holistic (thorough review) and thematic (appropriate discussion by theme). While interconnection requires an intersection between each of these scientific fields. (Hidayat, 2014)

In Islam, the position between science, social, and Islam is in integration, which interacts in a balanced and nondichotomic manner. Separating one of them can impact the breakdown of the chain of human and divine values so that the exact product is secularistic. Integration of science is hard work, but at least this effort must carry out tirelessly so that it can break the chain of apparent dichotomies that have occurred so far. Scientific efforts must always be made in Islam and become significant with the right application, one of which is through the Islamic education learning process. (Hidayat, 2014)

Islamic education, which has neglected the development of science and technology in the learning process, must be immediately disconnected. Islamic Character learning is in line with the noble values in the al-Quran and hadist. The Islamic character learning, which later became the character of Islamic education became a differentiator between knowledge originating from the West. Islam is not a secular religion that separates religious and world affairs. In Islam, religion underlies world activities, and world activities can support the implementation of religious teachings. With such characteristics, PAl does not dichotomize religion and other sciences. In Islam, religion sets goals that must be achieved by humans, while other sciences help accelerate the arrival of these goals. The science that comes from the ratio and its truth must be relatively subject to a religion whose absolute truth. Thus, Islamic education is not an exclusive and static science. However, open science accepts various influences from outside and continues to develop as long as it remains in line with the principles of Islamic teachings. (Nata, 2008)

Besides, Islamic learning also needs to be oriented on direct experience. According to Edgar Dale, one is learning outcomes obtained through direct experience (concrete). The reality exists in one's living environment than through artificial objects to the verbal symbol (abstract). The process of learning and teaching interaction does not have to be from direct experience. However, it begins with the type of experience that best fits the needs and abilities of the group of students faced by considering the learning situation. Direct experience will provide information and ideas contained in that experience, because it involves the senses of 
sight, hearing, feeling, smell, and touch. (Hidayat, 2014)

Dale believes that abstract symbols and ideas can be more easily understood and absorbed when given in the form of real experiences. The cone of experience is the beginning to explain the relationship between learning theory and audiovisual communication. Dale's cone experience is a direct depiction of reality as an experience that we first encountered. It is like this is the foundation of this cone of experience, which in this case, is still very concrete. In this stage, learning is done by holding, feeling, or directly on the subject matter. (Muhaimin, 2014)

This research discusses how integrative-interconnective implemented in Islamic education, especially in University. Because of the many problems of Islamic education in University. This research tries to give an alternative solution by learning innovation of the integrative-interconnective approach.

\section{RESEARCH METHOD}

This research categorized in naturalistic research with an interpretive paradigm (Moleong, 2005) and its type is Case Study (Yin, 2009). Data and sources include words and actions, then written data sources, photos, and statistical data. Data collection techniques include participant observation, in-depth interviews, and documentation. The sampling of research is purposive. (Cooper, 2012) So, the informant is selected suitable for research. The process started by seeking the critical informant from the lecturer, and then he will give who the next informant (snowball technique). After collecting the data, the next process is analysis. The technical analysis of the data using descriptive technique through interactive analysis model from Miles and Hubermen. (Hubermen, 2004) In the interactive analysis model, data collection, condensation data, data presentation, and conclusion are interactive (continuous, repetitive, and continuous) cycles and abstracting them into formal findings. While the techniques of checking the validity of data include: (1) credibility by using triangulation technique in methods and sources and member check done by confirming data to informants or other members. (Moleong, 2005) (2) Transferability by a full description (detailed description). (3) depend on the ability by involving a dependent auditor as an expert consultant that is the promoter and examiner. (4) confirmability is criteria for determining the quality of research results or not. Confirmability is required to know whether the data obtained objectively or not. All of the data collection results, conclusion, substantive findings and formal findings have confirmed to the owner of data or informants of research. (Lincoln, 1994)

\section{RESULTS AND DISCUSSION}


The innovation of Integrative and Interconnective Islamic Education based on Direct Experience

"Inovasi" is originated from English "innovation," which can translate as anything new or renewal. Indonesian Dictionary provides boundaries, innovation as an introduction of new things, discoveries that are different from those that already exist or that have been known before in the form of ideas, methods, or tools. (Poerwadarminta, 1990)

Beside "innovation," other terms are also found in both Indonesian and English. To clarify innovation, we formulate the term of discovery, invention, and innovation. Discovery is the discovery of something that exists but not yet known in general. The invention is the discovery of indeed something new and the result of human creation. While innovation is an idea of goods, events, or methods that are perceived or observed as new to someone or a group of people, it includes discovery and invention. (Rosyad, 2019)

It is like Haberman's idea stating that "innovation is the creative selection, organization, and utilization of new human and material resources and unique ways which will result in a higher level of achievement for the defined goals and objectives. Based on this opinion, innovation does not happen suddenly, but the innovations that occur have designed and planned in such away. According to Rogers, innovation is an idea, practice, or object that is perceived as new by an individual or other unit adoption. So, innovation is demand because of the development of creativity, an innovative mindset to students should be an essential thing in learning, including Islamic education subjects. (Mailani, 2018)

$$
\text { In Islam, religion underlies world }
$$
activities. It can support the implementation of religious teachings. With religion sets goals that humans must achieve, while other sciences help accelerate the arrival of these goals. The science that comes from the ratio and its truth must be relatively subject to a religion whose absolute truth. Thus, Islamic education is not an exclusive and static science. An open science accepts various influences from outside and continues to develop as long as these influences remain in line with the principles of Islamic teachings.

\section{Learning Paradigm}

The paradigm of Islamic education Learning in Universitas Brawijaya directed as integrative learning. Lecturers have the responsibility to associate the material taught with various disciplines, especially the disciplines that are occupied by students. As a Public Higher Education, Universitas Brawijaya students have diverse scientific backgrounds. Islamic education learning is carried out with critical, analytical, inductive, deductive, reflective 
discussion, through creative participatory dialogue to believe in the truth of the primary substance of the study and practice it.

2. Learning Approach

The Approach of Islamic education learning at Brawijaya University varies according to the character of the lecturer. Some lecturers use a spiritualscientific approach that is studentcentered oriented. The spiritual vision of Islamic Education in University becomes the primary substance of reasoning in the teaching and learning process, which refers to the appreciation and experience of Islamic teachings.

Islamic education must be able to make students aware of the human potential bestowed by Allah SWT, with the hope that the potential in the form of senses, intuition, reason, and other physical potentials utilized to the maximum extent possible. At least to defend himself spiritually or materially. Furthermore, Islamic education must also stimulate the soul and body's potential to move and be creative in seeking experiential opportunities for life to understand transcendental meanings. It is not an educational model that pumps the brain with various scientific information but never goes down to the heart to be selected. An empty heart of the spiritual meaning is a heart that is easily attacked by various diseases of materialism, which leads to covert atheism.

It is essential to equipped with a scientific approach. This approach is essential to develop the intellectuals because they are required to reason. Thus, they will accept Islam not only as a doctrine but also because they realize it through their thought processes. For example, about material for worship, if approached with science, the awareness of worship will strengthen. Why do we pray five times a day? Why do we have to fast? For what do we give alms? and others.

Besides, Islamic education learning in Universitas Brawijaya approached with various disciplines (multidisciplinary). To comprehensive knowledge, the teaching material should be the view from various perspectives. For this reason, learning developed in supporting learning.

This approach is not only implemented in core activities but also in learning support activities. Core learning activities implemented with the study of learning material analyzed from various perspectives (multidisciplinary). For example, creating the universe and humans is analyzed not only using modern science approaches but also philosophical and al-Quran approaches 
so that students' understanding more comprehensive.

Whereas in supporting learning can be implemented with tutorial or stadium general discussing Islam and multidisciplinary that are occupied by students. In these activities, students group based on the scientific background. Examples include Islamic studies and social sciences, Islam and natural science (agricultural, engineering, fisheries, and medical science)

Used other approaches are problem-solving, philosophical-normative, and Sufism approach. In learning, they always start with questions relating to problems that exist in society. The goal is that they are sensitive to problems in society and can solve them. In a philosophical-normative approach, all the material taught will be studied starting from the basics, the nagly argument (the al-Quran and the Hadis), the istinbat method\}, and others. With this approach, it expected that students' understanding would be more profound and comprehensive because students are required to know the lecture material in detail so that some problems arise. Whereas in the tasawuf approach, the lecturer is not orientation to his reasoning power, but also his heart. The reason to shape students' character, then both (mind and heart), must work together. For this reason, the method used is usually to play videos that can touch the hearts of students, such as videos about the torment of the grave.

3. Learning Strategy

The learning strategy applied by Islamic education lecturers in Brawijaya university is contextual teaching, learning, and problem-based learning. In this case, the lecturer gives students a stimulus to respond to the problems that arise in the community. In its implementation, at the beginning of learning, the lecturer always gives questions that can provide stimulus to students to be more active in the class. Analytical skills in problem-solving are also increasingly honed, and students become increasingly active in class, communicative, and rational. They not only argue based on mere assumptions, but also facts, reason, and arguments.

Problem-based learning strategies are applied to foster the spirit of student learning because students will study something close to the reality of their lives. It is also to develop students' reasoning power because they trained to solve problems that were important issues.

For the next activities, the lecturer maps the strategy to activities before and after the middle test. Before the middle test, lecturers had more active roles in learning because lecturers had to provide more understanding of the basics of 
Islamic teachings as provisions for observation tasks in the field. While after the middle test, students play a more active role in learning by presenting their observations. The theme of the observations adjusted to the material specified in the planning of lectures. Students will observe several places according to the theme under study. For example, the theme of Islamic morality is that students asked to observe how the problem of moral decline in their faculties and their solutions and contributions.

4. Learning Methods

The learning method innovation applied by Islamic education lecturers is a direct observation method. The lecturer assigns students to direct observations to several institutions or places related to the material taught. For example, for Islamic economic students asked to make observations to banks, Islamic political material students asked to make observations to political parties. By making direct observations, students learn many things. They learn to communicate with officials, adapt to new environments, selfstudy.

5. Learning Evaluation

Implemented evaluation of Islamic Education learning at Brawijaya University is following the learning objectives to achieve. At present, lecturers use more written tests, observations, and self-assessments. To find out the development of student character, lecturers make observations and self-assessments. To make observations, lecturers will attend students every meeting, so they can get to know one student united. In this way, the lecturer will know who is arriving late and how is his daily behavior. Lecturers also motivate students to be more active in class. Every student who contributes to lectures, whether in the form of questions, input, objections, or criticism, the lecturer will give a point. Later at the end of the lecture, the lecturer will recap the final results and get additional value for students who often contribute to learning.

While the lecturer gives the selfassessment method at the beginning and end of the lecture, the lecturer will previously make a grid or aspects that will be of value to be given and answered by students. They asked to judge themselves honestly. In this way, the lecturer will find out how the student changes after attending Islamic learning.

Based on the result of the final grade of the student, the understanding of student increases. Mostly, they get an A or B grade of Islamic education subject. Moreover, after interviewing the student, they recognize that learning innovation is 
important because they are bored if the method or learning approach is stagnant. They need a new approach and method to get a great understanding. So, the learning innovation of integrativeinterconnective is useful to increase their ability and understanding.

For more details on how innovation, it can be seen in the chart below:

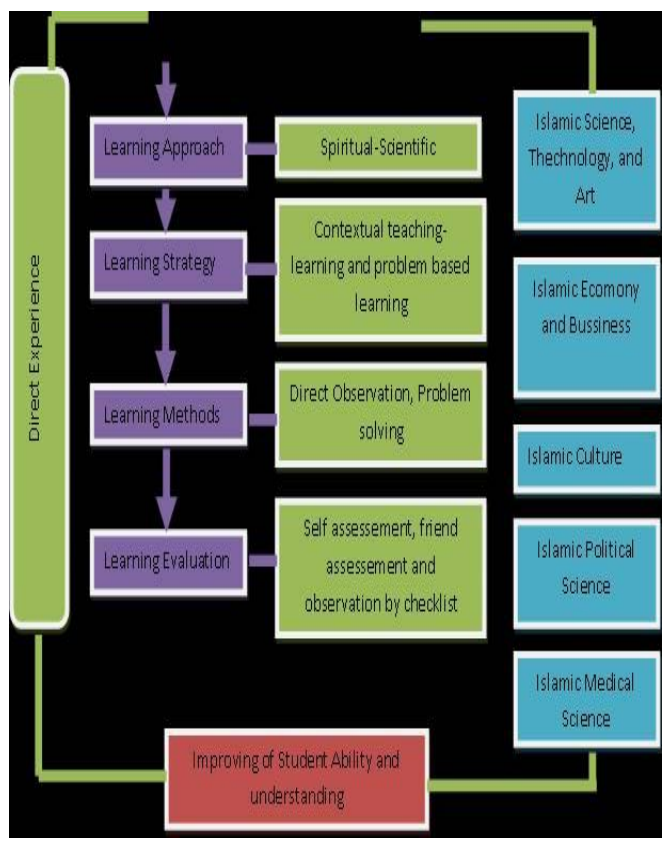

Picture 1: Innovation of Integrative-

interconnective Islamic Education based on direct experience in Universitas Brawijaya

\section{CONCLUSION}

The innovation of Islamic education learning at Brawijaya University includes several things, namely the paradigm, approach, strategy, method, and learning evaluation system. The learning paradigm changed from dichotomous to integrative- interconnective, where the Islamic Education course has a close relationship with several other disciplines. The learning approach oriented towards studentcentered with several focuses such as spiritual-scientific approaches, philosophicalnormative approaches, and problem approaches. Learning strategies include direct instruction, contextual teaching and learning, problem-based learning, and meaningful learning. The learning method oriented to the direct experience by assigning students to attend training in corpse care, specialized prayer training ', and direct observation to several places that are related to the material studied. At the same time, the evaluation does not only lead to cognitive aspects but affective and psychomotor aspects by using observation and self-assessment techniques.

\section{References}

Brill, C. A. (2003). Participatory Learning, Religious Education in a Globalizing Society. Leiden: Boston.

Cooper, K. a. (2012). Qualitative Research in the Post-Modern Era Contexts of Qualitative Research. Newyork: Springer.

Hamka. (2009). Rekonstruksi kurikulum Pendidikan Agama Islam di Perguruan Tinggi Umum pascapemerintahan orde baru. Hunafa.

hanafi, Y. (2016). DESAIN BAHAN AJAR MATAKULIAH PENDIDIKAN AGAMA ISLAM DENGAN PENDEKATAN INTEGRATIFINTERKONEKTIF ANTARA RELIGIOUS STUDIES, NATURAL SCIENCES, SOCIAL SCIENCES, DAN 
HUMANITIES . Tadris: Jurnal Keguruan dan Ilmu Tarbiyah , 134.

Hidayat, M. (2014). Pendekatan IntegratifInterkonektif: Tinjauan Paradigmatik dan Implementatif dalam pembelajaran Pendidikan Agama Islam. Ta'dib , 277.

Hubermen, M. a. (2004). Analisis data kualitatif.

Lincoln, N. K. (1994). Hand Book of Qualitative Research. London, New Delhi: Sage Publication.

Mahpudz, A. (2011). Pembangunan Karakter dan Kepribadian Mahasiswa pada Pembelajaran di Perguruan Tinggi.

Mailani, I. (2018). Inovasi Pembelajaran Pendidikan Agama Islam Berbasis Problem Based Learning. al-Uswah: Jurnal Riset dan Kajian islam , 134-135.

Moleong, L. J. (2005). Metedologi Penelitian Kualitatif. Bandung: Remaja Rosdakarya.

Muhaimin. (2014). Muhaimin, Model Pengembangan Kurikulum dan Pembelajaran dalam Pendidikan Islam Kontemporer, (Malang: UIN Maliki Press, 2015), hlm. 55. Malang: UIN Maliki Press.

Munip, A. (2008). Perkuliahan Pendidikan Agama Islam di Perguruan Tinggi Negeri. Jurnal Pendidikan Agama Islam .
Nata, A. (2008). Ilmu Pendidikan Islam dengan Pendekatan Multidisipliner. Jakarta: Rajawali Press.

Poerwadarminta, W. (1990). Kamus Besar Bahasa Indonesia. Jakarta: Balai Pustaka.

Rosyad, A. M. (2019). THE URGENCY OF LEARNING INNOVATION ON ISLAMIC RELIGIOUS STUDY. Al-Afkar: Journal of Islamic Studies, 64.

Said, M. T. (2018). Innovation In Islamic Education. Hayula: Indonesian Journal of Multidisciplinary Islamic Studies, 118.

Saidah, N. (2007). Pendidikan Agama Islam, Problem dan Tantangannya sebagai komponen matakuliah pengembangan kepribadian (MPK). Jurnal Pendidikan Agama Islam .

Sumarno. (2008). Model Pembelajaran Pendidikan Agama Islam berdasarkan Contextual and Teaching (CTL).

widodo, S. F. (2009). Peningkatan perilaku religius mahasiswa melalui integrasi pembelajaran pendidikan agama Islam (PAI) dan pembinaan di unit kegiatan keagamaan mahasiswa. Jurnal Humanika MKU Universitas Negeri Yogyakarta .

Yin, R. K. (2009). Case Study Research: Design and Methods. United Kingdom: SAGE. 